\title{
Implementation Of Civil Education As Character Education In
}

\section{Schools}

\author{
Rinita Rosalinda Dewi ${ }^{1)}$, Sofyan Sauri ${ }^{2)}$, Aceng Kosasih ${ }^{3)}$ \\ Study Program of General and Character Education Setiabudi No. 229, Isola, Sukasari district, Bandung \\ City, West Java, Indonesia ${ }^{1,2,3)}$ \\ rinitarosalindadewi@upi.edu ${ }^{1)}$, sofyansauri@upi.edu 2), acengkosasih@upi.edu ${ }^{3)}$,
}

\begin{abstract}
This study aims to determine how the implementation of civic education as character education in schools, especially at SDN 077 Sejahtera, Bandung. The research focus is on religious character, national spirit, curiosity, responsibility, friendly/communicative, and hard work. This study used a qualitative descriptive-analytical method. The instruments used were observation, interview, and documentation study. The results of this study indicate that (1) Planning the implementation of civic education as character education in schools, especially SDN 077 Sejahtera, has been prepared in learning planning, namely in syllabus and character lesson plans. (2) The implementation of civic education as character education in schools, especially at SDN 077 Sejahtera, namely Civics teachers have implemented and used various learning methods and resources and integrated various characters in activities. (3) Evaluation of the implementation of civic education as character education in schools, especially at SDN 077 Sejahtera, namely the teacher has carried out various assessments such as written tests but is still not maximal in assessing the attitudes of students during the learning process. (4) The constraints on the implementation of civic education as character education in schools, especially at SDN 077 Sejahtera are that learning time is considered very fast so that the assessment of student attitudes is not optimal, and character education at home is lacking, so that character education in schools is also less than optimal.
\end{abstract}

Keywords: Civic Education; Character Education; School

\begin{abstract}
Abstrak. Penelitian ini bertujuan untuk mengetahui bagaimanakah Implementasi Pendidikan Kewarganegaraan sebagai sebagai Pendidikan Karakter di Persekolahan khususnya di SDN 077 Sejahtera, Bandung. Adapun fokus penelitian pada karakter religius, semangat kebangsaan, rasa ingin tahu, tanggung jawab, bersahabat/komunikatif dan kerja keras. Penelitian ini menggunakan metode kualitatif deskrptif analitis. Instrumen yang digunakan observasi, wawancara, dan studi dokumentasi. Hasil penelitian ini menunjukkan bahwa (1) perencanaan implementasi pendidikan keawarganegaraan sebagai pendidikan karakter di persekolahan khususnya di SDN 077 Sejahtera telah disiapkan dalam perencanaan pembelajaran yaitu dalam silabus dan RPP berkarakter. (2) pelaksanaan implementasi pendidikan kewarganegaraan sebagai pendidikan karakter di persekolahan khususnya di SDN 077 Sejahtera yaitu guru PKn telah menerapkan dan menggunakan metode dan sumber belajar yang beragam serta mengintegrasikan berbagai karakter dalam kegiatan. (3) Evaluasi implementasi pendidikan kewarganegaraan sebagai pendidikan karakter di persekolahan khususnya di SDN 077 Sejahtera yaitu guru telah melakukan berbagai penilaian seperti tes tulis, tetapi masih kurang maksimal dalam melakukan penilaian terhadap sikap peserta didik selama proses pembelajaran. (4) Kendala implementasi pendidikan kewarganegaraan sebagai pendidikan karakter di persekolahan khususnya di SDN 077 Sejahtera adalah waktu pembelajaran dianggap sangat cepat, sehingga penilaian terhadap sikap siswa kurang optimal, dan pendidikan karakter dirumah yang kurang, sehingga pendidikan karakter di sekolah juga kurang optimal.
\end{abstract}

Kata Kunci: Pendidikan kewarganegaraan, Pendidikan karakter,Sekolah 


\section{INTRODUCTION}

The 21st century is the century of culture and education (Zakiyah and Rusdiana, 2014, p. 59) which is marked by the availability of easily accessible information, advanced technology, a rapidly changing society, and high competitiveness. Of the many changes that have occurred, at least some are permanent and agreed by all countries in the world that education has two main objectives, first to help students become smarter, and second to help students become better (Lickona, 2012, p. 5). As civilization advances in this century, teachers and students as a component of education are required to have the learning ability of the 21 st century.

According to BSNP (2010), the challenges facing education in the 21 st century include critical thinking and problem-solving skills, communication and collaboration skills, creativity and renewal skills, information and communication technology literacy, contextual learning skills, as well as information and media literacy skills. . By facing the challenges of education in the 21 st century, will encourage the realization of the ideals of the Indonesian state, namely prosperity and happiness by forming a society consisting of quality human resources, namely individuals who are independent and willing, so that they can realize the ideals of the country and equal to other countries in the world (Haryanto, 2019). But the reality is that the education system in Indonesia has not been able to face the challenges of 21st-century education. This can be seen from the one-way learning model that is still running in most schools so that students only know and listen to the teacher's explanation. Another condition can be seen from the habits of less creative students, lack the ability to innovate, have poor problem-solving abilities, and are not used to two-way communication (Lydiasari, 2018).

Another problem in 21st-century education, especially those experienced by teachers, is the cultivation of character education because the teacher's job is not to educate students only but how to transform them into pious individuals, individuals with integrity, disciplined personalities, creative and curious personalities, as well as a person who continues to be enthusiastic and continues to respect others (Nuraini, 2019). Education is defined as a conscious and planned effort that aims to develop students' potential and make them better human beings (Sauri, \& Budimansyah, 2014, p. 24; Sauri, \& Nurdin 2019, p. 34). Besides, education also functions to develop abilities, shape personality, and create a dignified national civilization and educate the nation's life. The meaning of dignified education here is to develop the potential of students and make them people who believe and fear God Almighty, have a noble character, are healthy, knowledgeable, capable, creative, independent, and become democratic and responsible citizens (Prasetyo \& Marzuki, 2016, pp. 215-216). Meanwhile, 
the character is a unique value in character, morality and personality, which is formed through the internalization of various policies that are considered and used as a way of observation, thinking, behaviour, conversation and behaviour in everyday life (Wahyu, 2011, p. 141; Putra, 2017, p. 49). So it can be concluded that character education is a conscious and planned effort through a learning environment that aims to encourage the growth and development of all human potential, so that they have a good personality and character, and have a good impact on nature and society. Character education can also be interpreted as a guidance process that helps to grow, develop, mature, and shape a person's personality which is a person's traits or character (Shenfield, 2016, Putra, 2017; White \& Shin, 2017).

One of the ways to achieve this is through educational institutions, especially schools. Schools are formal educational institutions that are expected to meet academic targets and implement the urgency of character education. The school consists of various levels, be it Kindergarten, Elementary School, Junior High School, Senior High School, College and other schools that have equal levels (Permendikbud, 2019). Elementary school (SD) is one of the regular schools and is the basis for further studies.

The implementation of character education in elementary schools can be incorporated into the learning process such as various subjects that come into direct contact with religion or educational material (Julaiha, 2014). One of the subjects that can provide character development is Citizenship Education. Citizenship education (Civics) is essentially an educational program that has discussions about nationality, citizenship issues related to the state, democracy, human rights and civil society, and applies the principles of democracy and humanistic education (Dianti, 2014; Juliardi, 2015). Another view says that civic education aims to remind citizens of the importance of values, rights and obligations so that everything that is done is in line with the goals and ideals of the country and does not deviate from expectations (Swalwell, 2015; Llano, 2017; Ngozwana, 2017) .

However, in the implementation process, Civics subjects face several obstacles, namely being considered less attractive, trivial, boring, teacher-centred, many lectures, developing a memorizing culture, textbookbased teaching, and the position of teachers who still transfer knowledge and emotions/attitudes of students who related to the process of personality formation is often neglected (Setiawan, 2014).

Therefore, Civics learning needs to be improved by developing student character starting from planning, process/implementation, evaluation, and the obstacles that will be experienced. There have been many studies on civic education as 
character education in schools (Kurniawan, 2013; Karimah, 2015; Suardi, et al, 2019). Furthermore, for the concept of character education, there have been several studies (Cahyono, 2015; Nastiti, 2017; Sugiana, 2019). This research has been carried out at the middle and upper levels. At the university level, there are also several studies on civic education as higher character education (Dhiu \& Bate, 2017; Mansir, 2017; Hidayah, Ulfah, \& Suyitno, 2019). Based on the various problems discussed in the previous paragraph, the writer tries to trace the root of the problem that is currently happening, especially in the implementation of civic education as character education in school.

\section{RESEARCH METHODS}

This research used qualitative research methods to clearly reveal the facts about the phenomena that occur in the field, then carry out an in-depth analysis of the results. Qualitative research aimed to comprehend the phenomena experienced by the object of research in a comprehensive manner, such as perception, motivation, self-action, and description through language and forms of language through the use of special natural contexts and various scientific methods (Moleong, 2007, p. 6). The research design in this research was through case studies. The participants in this study consisted of Pkn teachers and students. Researchers selected these participants based on their understanding of the problems in the research being carried out. The research site was conducted at SDN 077 Sejahtera Sukajadi, Bandung City. The type of data disclosed in this study is narrative, participant data is described and explained in the form of oral and written document data, and participant behaviour that was observed directly on the spot was also the data to collect the results of this study. The steps for implementing the research were collecting interview data from sources, which were then processed, the results of field observations, collecting documents related to character education through Civics in schools. Then did the overall data collection by making data descriptions and the next step was to analyse the data that had been collected.

\section{DISCUSSION}

The Civics subject is actually one of the subjects that has many character values because this subject is one of the main sectors in the cultivation of character education. But in reality, Civics are not considered important, because they are considered to have a lot of memorization material and cannot carry out its function as the main sector of character education. In fact, in Civics there are two important character values, namely the main character values and the main character values. The main character values aim to create students who are religious, honest, smart, tough, democratic, and caring. Meanwhile, the main character values aim to create students 
who are nationalist, obey social rules, respect diversity, are aware of the rights and obligations of themselves and others, are responsible, think logically, are critical, creative, and innovative, and independent (Juliardi, 2015). Listyarti (2012, pp. 5-8) states that there are 18 national character values that must be inserted in education, namely religion, honesty, tolerance, discipline, hard work, creative, independent, democratic, curiosity, national spirit, love for the country., respect for achievement, friendly/communicative, love peace, love to read, care for the environment, care for social, and responsibility. Therefore, the researcher conducted a series of activities that allowed Civics subjects to instil character education in students, especially religious character, national spirit, curiosity, responsibility, friendly/communicative and hard work.

Based on the research results, SDN 077 Sejahtera teachers stated that character education is education related to student attitudes and behaviour so that individual students become better. This is in line with the Ministry of Education and Culture (2016) which suggests that character education is an educational movement in schools that aims to shape, transform, spread and develop the potential of students by coordinating hearts, feelings, thoughts and movements in accordance with the philosophy of life in Pancasila. Therefore, as educators, teachers have an obligation to instil character education in students. This can be started by giving examples / exemplary during teaching and learning activities in class because, in addition to teaching the duties and obligations of the teacher, they must also become role models and facilitators for students.

Planning for the implementation of civic education as character education at SDN 077 Sejahtera, especially those carried out by Civics teachers, namely preparing lesson plans consisting of an annual program (prota), a semester program (promes), a syllabus, a Learning Implementation Plan (RPP) which contains character values which will be developed. Mulyasa in Dianti (2014, p. 231) states that learning planning includes at least three activities, namely determining needs, determining competencies and preparing learning plans. Meanwhile, according to Hamalik (2009, p. 50), the things that must be considered in preparing the RPP are:

1. The plan developed must adapt to existing resources.

2. The learning organization must always pay attention to the situation in the school environment.

3. Teachers who are managers of learning must take full responsibility for their responsibilities and functions.

In the implementation of civic education as character education at SDN 077 Sejahtera, this learning plan serves to determine the activities to be achieved and how to achieve them, how long it will take, 
how many people will be needed, and what must always be prepared in planning the lesson. In order to compile syllabus and lesson plans, the school always contains values, attitudes and behaviours that can facilitate the learning process and encourage the formation of student character in accordance with the planned learning objectives. The purpose of preparing this lesson plan and syllabus is to encourage each teacher to prepare teaching and learning activities that can help shape students' abilities and character (Karimah, 2015). The concept of syllabus and character lesson plans itself aims to facilitate the learning process and shape the character of students according to what has been planned. This is in line with Mulyasa's (2011, p. 83) view that the planning stage for character education in Civics learning includes the preparation of a syllabus and lesson plans, where these activities must develop attitudes, values and behaviour and in compiling this syllabus and lesson plans must facilitate the learning process in forming the character of students.

At the implementation stage of the implementation of civic education as character education at SDN 077 Sejahtera, teachers carry out teaching and learning activities in accordance with the character lesson plans that have been previously made. In the early learning activities, the teacher always habituates by carrying out prayers according to their respective religions and also singing the
Indonesia Raya song or other national compulsory songs to instil a religious and nationalistic attitude in students. This religious character value reflects faith in God Almighty, which is reflected in the act of carrying out his religious teachings (Dewi, Suresman, \& Mustikasari, 2020). Meanwhile, the value of the character of nationalism / national spirit reflects attitudes or actions in protecting and protecting the nation and placing the interests of the nation and state above personal or group interests (Annisa, Hasibuan, \& Siregar, 2020). Then, the teacher also provides an example/role model by coming to teach on time, dressed neatly and politely when teaching in class, and paying attention to class tidiness. This role model is very important and has a major contribution to education and character building, because it puts forward all aspects of behaviour in the form of practical action, not just talking (Prasetyo \& Marzuki, 2016). Therefore, this teacher's example becomes one of the most important factors for the effectiveness of character education in schools.

Furthermore, teachers also use appropriate learning methods to instil character education in students. This can be seen when carrying out teaching and learning activities, where the teacher always creates a learning atmosphere through the steps of teaching and learning activities, namely:

1. The teacher gives students a stimulus to encourage students to explore by asking 
questions, thereby providing stimulation through questioning skills.

2. After being stimulated, students receive student worksheets (LKS) given by the teacher, so that students have the opportunity to find problems through discussions with friends, and this aims to foster curiosity and student responsibility.

3. Students gather relevant information to help them complete worksheets through various sources such as printed books and the internet.

4. After collecting data, students process the data obtained by discussing with friends and selecting relevant information to fill in the worksheets, then confirming the data obtained and answering questions on the LKS. Through these activities, students will indirectly develop a friendly/communicative character and work hard. Friendly/communicative character values reflect the ability to convey ideas/ideas to others so as to create a pleasant atmosphere when working together (Hanum \& Meilinda, 2019). Meanwhile, the character value of hard work reflects a serious attitude in achieving goals, overcoming obstacles in completing a task or job (Wuryanti \& Kartowagiran, 2016).

5. Finally, the teacher asks each group to explain the results of the discussion and draw conclusions about the material that was studied together.
The last stage in character Civics learning is the closing activity. In the closing activity, the teacher integrates character values in accordance with the lesson plans that have been prepared previously. So, the teacher does the closing activities well and this is very helpful for cultivating character education for students.

In addition, based on the data obtained by researchers through direct observation and interviews in the field, researchers found that the evaluation/assessment techniques in Civics learning were not yet diverse. Teachers only evaluate student assignments in written form and do not fully evaluate students' attitudes during the learning process. In fact, when viewed from the perspective of learning evaluation theory, teachers can evaluate through observation, interviews, anecdotal notes, graded scales, self-assessment, peer-topeer assessments, and portfolios (Ratnawulan \& Rusdiana, 2014). Then, in this study, the researcher also found several obstacles during the implementation of civic education as character education at SDN 077 Sejahtera. The first obstacle is that sometimes-teaching activities are too fast so that the assessment of student attitudes is not optimal. The solution is to solve the problem of time so that the teacher can optimally evaluate attitudes towards students. The second obstacle is the lack of character education in the family, so that character education in schools is not optimal. The solution taken is that schools provide 
opportunities for children to get character education at home on weekends, namely Saturdays and Sundays. In addition, the school also invites parents of students to exchange information about knowledge related to character education carried out by schools, so that parents can participate in providing character education to their children.

\section{CONCLUSION}

Based on the results of the previous research and discussion, several conclusions were obtained, namely planning the implementation of civic education as character education in schools, especially at SDN 077 Sejahtera, namely in the learning planning, the character values developed in the RPP were included and immediately added them into learning activities, where This is done by modifying the RPP character based on the type of character to be achieved. Then the implementation of civic education as character education in schools, especially at SDN 077 Sejahtera, namely by applying and using various learning methods and resources, and incorporating various characters into learning activities, such as being religious when worshipping, national spirit when singing various national compulsory songs, developing a sense of want and responsibility when discussing, and friendly/communicative and work hard to find all kinds of information. Evaluation of the implementation of civic education as character education in schools, especially at SDN 077 Sejahtera, namely the teacher has made various assessments such as written tests, but it is still not optimal when assessing the attitudes of students during the learning process. The obstacle to the implementation of civic education as character education in schools, especially at SDN 077 Sejahtera is that learning time is considered very fast so that the assessment of student attitudes is less than optimal, and character education at home is lacking, so that character education in schools is also less than optimal.

\section{REFERENCES}

[1] Annisa, N., Hasibuan, P. H., \& Siregar, E. F. S. (2020). Menyanyikan Lagu Indonesia Raya sebagai bentuk Impelementasi Penguatan Pendidikan Karakter di SDS Asuhan Jaya Kota Medan. Jurnal Benderang, 1(1), 1-5.

[2] BSNP. (2010). Laporan BSNP Tahun 2010. Jakarta: Badan Standar Nasional Pendidikan.

[3] Cahyono, H. (2015). Pola Pengembangan Pendidikan Karakter Siswa. Jurnal Dimensi Pendidikan dan Pembelajaran, 3(2), 5-12.

[4] Dewi, R. R., Suresman, E., \& Mustikasari, L. (2020). Implementasi Kebijakan Mata Kuliah Pendidikan Kewarganegaraan Sebagai Pendidikan Karakter di Perguruan Tinggi: Jurnal Edueksos (The journal of social and economics education), IX(1), 1-15.

[5] Dianti, P. (2014). Integrasi Pendidikan Karakter dalam Pembelajaran Pendidikan Kewarganegaraan untuk Mengembangkan Karakter Siswa: JPIS (Jurnal Pendidikan Ilmu Sosial), 23(1), 58-68.

[6] Dhiu, K. D.,\& Bate, N. 2017. Pentingnya Pendidikan Karakter di Perguruan Tinggi: Kajian Teoritis Praktis: 2nd Annual Proceesding STKIP Citra Bakti Bajawa NTT, 172-176. 
[7] Hamalik, O. (2009). Perencanaan Pengajaran Berdasarkan Pendekatan Sistem. Jakarta: PT Bumi Aksara.

[8] Hanum, A., \& Meilinda, A. (2019). Studi Karakterisasi Bersahabat/Komunikatif Pada Siswa SMPN 18 Kota Jambi. Jurnal Publikasi Pendidikan, 9(2), 147-151.

[9] Haryanto, R. (2019). Tranformasi Pendidikan Abad 21 Melalui Rumah Belajar. [Online]. Tersedia http://pena.belajar.kemdikbud.go.id/2019/07/ tranformasi-pendidikan-abad-21-melaluirumah-belajar/. Diakses pada 30 Mei 2020.

[10] Hidayah, Y., Ulfah, N., \& Suyitno. (2019). Pendekatan Pembelajaran Mata Kuliah Wajib Umum Pancasila dan Pendidikan Kewarganegaraan di Perguruan Tinggi.Jurnal Pancasila dan Kewarganegaraan, 4(1), 22 33.

[11] Julaiha, S. (2014). Implementasi Pendidikan Karakter DalamPembelajaran. Dinamika Ilmu, 14(2), 226-238.

[12] Juliardi, B. (2015). Implementasi Pendidikan KarakterMelalui Pendidikan Kewarganegaraan. JURNAL BHINNEKA TUNGGAL IKA, 2(2), 119-126.

[13] Karimah, M. (2015). Implementasi Pendidikan Karakter Dalam Pembelajaran Pendidikan Kewarganegaraan Di Madrasah Salafiyah Ibtidaiyah. IJCETS (Indonesian Journal of Curriculum and Educational Technology Studies), 3(1), 49-55.

[14] Kemendikbud. (2016). Konsep dan Pedoman Penguatan Pendidikan Karakter. Jakarta: Kementerian Pendidikan dan Kebudayaan.

[15] Kurniawan, M. I. (2013). Integrasi Pendidikan Karakter ke dalam Pembelajaran Kewarganegaraan di Sekolah Dasar. Jurnal Pemikiran dan Pengembangan SD, Jilid 1, No. 1, 37-45.

[16] Lickona, T. (2012). Character Matters. Jakarta: PT Bumi Aksara.

[17] Llano, S. M. (2017). The counterfeit presentment: an early 20th century model of intercollegiate debate as civic education. Argumentation and Advocacy, 53(2), 90-102. http://dx.doi.org/10.1080/00028533.2017.13 $\underline{04983}$.

[18] Listyarti, R. (2012). Pendidikan Karakter dalam Metode Aktif, Inovatif, \& Kreatif. Jakarta: Esensi.

[19] Lydiasari, P. (2018). Sistem Pendidikan di Indonesia Belum Siap Hadapi Abad 21.[Online].Tersedia di https://www.suaramerdeka.com/news/baca/1 28753/sistem-pendidikan-di-indonesiabelum-siap-hadapi-abad-21. Diakses pada 30 Mei 2020.

[20] Mansir, F. (2017). Model Pendidikan Karakter di Perguruan Tinggi Islam. (Disertasi). SPS UIN Syarief Hidayatullah Jakarta.

[21] Moleong, L., J. (2007). Metodologi Penelitian Kualitatif. Edisi Revisi. Bandung: PT Remaja Rosdakarya.

[22] Mulyasa. (2011) Manajemen Pendidikan Karakter. Jakarta: Bumi Aksara.

[23] Nastiti, D. (2017). Implementasi Karakter Tanggung Jawab dalam Pembelajaran PPKn melalui Model STAD berbasis Joyfull Learning: Prosiding Konferensi Nasional Kewarganegaraan III Universitas Ahmad Dahlan, Yogyakarta, 209-213.

[24] Sugiana, A. (2019). Penanaman Nilai Karakter Disiplin dan Tanggung Jawab di SMK Ethika Palembang.Jurnal PAI Raden Fatah, 1(1), 105-116.

[25] Ngozwana, N. A. (2017). Civic education in Lesotho: implications for teaching of democratic citizenship. International Journal of Lifelong Education, 36(5), 526-540. https://doi.org/10.1080/02601370.2017.1304 $\underline{460}$.

[26] Nuraini, R. 2019. Dirjen Pendis: Pendidikan Karakter Tantangan Abad 21 dan Kuncinya Guru. [Online].Tersedia di https://jpp.go.id/humaniora/sosialbudaya/336107-dirjen-pendis-pendidikankarakter-tantangan-abad-21-dan-kuncinyaguru. Diakses pada 30 Mei 2020.

[27] Permendikbud. (2019). Pedoman Organisasi dan Tata Kerja Satuan Pendidikan Dasar dan 
Menengah. Jakarta: Kementrian Pendidikan dan Kebudayaan.

[28] Prasetyo, D.,\& Marzuki. (2016). Pembinaan Karakter melalui Keteladanan Guru Pendidikan Kewarganegaraan di Sekolah Islam Al Azhar Yogyakarta.Jurnal Pendidikan Karakter, Tahun VI, Nomor 2, 215-231.

[29] Putra, P. (2017). Implementasi Pendidikan Karakter dalam Pembelajaran IPA di MIN Pemangkat Kabupaten Sambas Kalimantan Barat: Jurnal Ilmiah PGMI, 3(1), 49-61.

[30] Ratnawulan, E., \& Rusdiana, A. (2014). Evaluasi Pembelajaran. Bandung: Pustaka Setia.

[31] Sauri, S., \& Budimansyah, D. (2014). Nilai kearifan Lokal Pesantren Lokal Pesantren dalam Upaya Pembinaan Karakter Santri.NIZHAM, 3(02), 21-50.

[32] Sauri, S., \& Nurdin, D. (2019). Manajemen Pendidikan Berbasis Nilai. Cetakan Kesatu. Bandung: Refika Aditama.

[33] Setiawan, D. (2014). Pendidikan Kewarganegaraan Berbasis Karakter melalui Penerapan Pendekatan Pembelajaran Aktif, Kreatif, Efektif dan Menyenangkan.Jurnal Pendidikan Ilmu-Ilmu Sosial, 6(2), 61-72.

[34] Suardi, dkk. (2019). Implementasi Pendidikan Karakter Melalui Mata Pelajaran Pendidikan Kewarganegaraan di SMA Jaya Negara Makassar.Jurnal Etika Demokrasi, 4(1), 2229.

[35] Swalwell, K. (2015). Mind the civic empowerment gap: Economically elite students and critical civic education. Curriculum Inquiry, 45(5), 491-512. https://doi.org/10.1080/03626784.2015.1095 624.

[36] Wahyu. (2011). Masalah dan Usaha Membangun Karakter Bangsa.Jurnal Komunitas, 3(2), 138-149.

[37] Wuryanti, U., \& Kartowagiran, B. (2016) Pengembangan Media Video Animasi Untuk Meningkatkan Motivasi Belajar Dan Karakter Kerja Keras Siswa Sekolah Dasar. Jurnal Pendidikan Karakter, VI(2), 232-245.
[38] Zakiyah, Q.Y., \& Rusdiana. (2014). Pendidikan Nilai: Kajian Teori dan Praktik di Sekolah. Bandung: CV Pustaka setia. 